\title{
Obesidade: Genética, Fisiopatologia e Terapêutica às Vésperas de uma Importante Revolução Conceitual
}

A PARENTEMENTE PRETENSIOSO, O TÍTULO deste editorial não é originalmente meu, mas emprestado de um simpósio realizado há menos de dois meses (25 a 27 de novembro de 1999), no Instituto Pasteur, em Paris. Fez parte de um programa continuado de atualização daquela instituição, chamado Euro Conferências, coordenado desde há muito por um brasileiro radicado em Paris - e conhecido de muitos de nós -, B. Boris Vargaftig. A programação científica deste simpósio em particular foi elaborada por uma comissão que incluía, além de José Caro, Philippe Froguel e Mark McCamish, outros dois brasileiros que vivem no exterior: Julio Licínio e André Negrão.

Esta edição especial dos Arquivos, coordenada por Alfredo Halpern (cidadão brasileiro com raízes francesas? - vejam no final a razão desta interrogação), é dedicada ao tema atualíssimo e foi preparada com muito carinho para mostrar a relevância e a abrangência do tema.

Tive a oportunidade de atender àquela EuroConferência e fiquei verdadeiramente impressionado não apenas com o temário, que procurei resumir em seguida, mas principalmente pelo fato de que entre os 171 indivíduos presentes, 78 pertenciam aos staffs de empresas privadas do ramo da indústria farmacêutica ou congêneres (Knoll, Lipha, Servier, Sanofi, Roche, Merck, Sharp \& Dohme, Solvay, Rhône-Poulenc, Novartis, Hoescht, Glaxo, Bristol-Myers-Squibb, Amgen, Zeneca, etc).

Descobri, no decorrer do evento, que um dos objetivos destas EuroConferéncias, é colocar lado a lado, debatendo, discutindo e apresentando dados até o limite da confidencialidade pertinente às novas descobertas científicas (envolvendo direito a patentes, etc), pesquisadores ligados à academia e à indústria farmacêutica ou instituições privadas. É curioso como, resguardando dados novos ainda não publicados, houve ampla troca de informações de indiscutivel interesse para pesquisadores de ambos os lados.

Dentre as inúmeras novidades (das quais eu abordarei apenas um reduzido número), foram desenvolvidos alguns conceitos preliminares sobre o circuito cerebral que regula a ingestão de alimentos: Steve Bloom enfocou as interações hipotalâmicas do núcleo arqueado que afetam o apetite, explorando os efeitos inibitórios do $\alpha$-MSH e do CART (cocaineamphetamine regulated transcript), e estimulatórios do NPY (neuropeptídeo Y) e AgRP (agouti-related peptide); Jeffrey Flier mostrou dados relativos às ações centrais e periféricas da leptina $\mathrm{em}$ condições fisiológicas $\mathrm{e}$ em modelos resistentes à leptina, enfocando a barreira hemato-liquórica, as vias de transdução do sinal da leptina nos neurônios-alvo e o papel dos seus inibidores, especialmente a SOCS-3 (suppressor of cytokine signaling-3), na gênese da resistência à leptina.

Julio Licinio apresentou dados inusitados sobre pulsatilidade e ritmicidade circadiana das concentrações de leptina circulante, que influenciam a atividade dos eixos hipotálamo-hipófise-ovário e adrenal, indicando que a leptina - produzida fundamentalmente pela massa de tecido adiposo (até hoje considerado inerte do ponto de vista endócrino) possa ser um
Claudio E. Kater

Editor-Chefe, $A B E \mathcal{O} M$ 
modulador da reprodução e da função endócrina relacionada ao stress e ao comportamento.

Pierre Bougnères e Jacques Pairault abordaram aspectos do controle da expressão gênica durante a diferenciação das várias linhagens de adipocitos e suas anormalidades que poderiam estar envolvidas na gênese da obesidade juvenil e do adulto. O programa de diferenciação dos adipocitos parece ser controlado pela expressão seqüencial de fatores nucleares de transcrição recentemente identificados, como o C/EBP (CCAAT/enhancer binding protein), PPAR (peroxisome proliferator-activated receptor) e o LIF (leukemia inhibitory factor).

Por outro lado, Margarita Lorenzo mostrou que células do tecido gorduroso branco e marrom são constitutivamente refratárias a apoptose. Entretanto, adipocitos marrons "imortalizados" respondem à deprivação de nutrientes séricos com parada de crescimento e subseqüente apoptose, processo mediado pela ativação de caspases e que envolve tanto a indução da expressão dos gens pró-apoptóticos Bcl-Xs como a inativação do gen anti-apoptótico $\mathrm{Bcl}-2$. Interessantemente, insulina e IGF- 1 recuperam os adipocitos marrons da apoptose através da supressão (down-regulation) da expressão de Bcl-Xs.

Porquanto a secreção de leptina pelos adipocitos garantiu ao tecido adiposo a posição de órgão endócrino, a lista de outros hormônios produzidos por este tecido cresceu de tal maneira que possibilitou categorizá-lo como senão o mais importante pelo menos o mais versátil tecido endócrino já conhecido. Gérard Ailhaud mostrou que produtos tão variados como angiotensina II; PAI-1, TNF- $\alpha$, IL- 6 , adiponectina, precursores esteróides, estrógenos, IGF-1, adipsina, etc, podem ser produzidos, até abundantemente, pelos adipocitos.

Os grupos de Stephen O’Rahilly e Philippe Froguel, em estudos distintos, concluem que embora mutações raras tenham sido identificadas nos genes da leptina e do seu receptor, na POMC (pró-opiomelanocortina) e no receptor da MC4 (melanocortina-4), resultando em graus extremos de obesidade, estes genes não parecem ter qualquer papel nas formas mais comuns de obesidade. Assim, propõem que sejam conduzidos estudos mais amplos "escaneando" todo o genoma à procura do gene da obesidade humana, utilizando "positional cloning".

Uma variedade de drogas para controle do apetite e da saciedade foram discutidas, desde novos aspectos do uso da sibutramina, até moléculas experimentais com potencial de utilização. Mark McCamish mostrou que o emprego da leptina sintética é eficaz na perda de peso de pacientes de uma família de origem árabe portadora de deficiência da leptina, mas não em pacientes obesos de outras causas, excluindo a leptina como uma droga de uso promissor na obesidade simples. Entretanto, sinalizou, sem apresentar dados, que vários análogos sintéticos da leptina, desenvolvidos em sua empresa, têm mostrado resultados surpreendentes.

Assim, depois de inúmeros dados que estão elucidando a bioquímica dos mecanismos fisiopatológicos da obesidade, uma pletora de novas proteínas envolvidas na regulação do peso corpóreo (liçōes apreendidas de modelos animais de obesidade) deverá oferecer alvos "inteligentes" para o desenvolvimento de novas drogas. Resta esperar.

Sem me alongar muito, e apenas lamentado não poder transcrever mais e melhor as informações apresentadas naquele evento, deixo os leitores com este número especial da revista e a vasta e importante coletânea de dados sobre obesidade que estão sendo gerados por pesquisadores nacionais, e que poderia muito bem estar sendo publicada numa revista estrangeira não fosse a minha insistência com nosso caro Alfredo para que intercedesse junto aos autores e desviasse boa parte deste material para os nossos "Arquivos".

Finalizo agradecendo a todos os colaboradores desta edição especial, e principalmente ao Alfredo Halpern pela sua proficiência como editorconvidado. Deixo, como dedicatória a ele, a foto ao lado, tomada numa praça charmosa dos arredores de Paris e que caracteriza o elo que poucos conheciam entre França e Brasil e, particularmente, entre Bernardos e Halperns, na figura de um médico (certamente brilhante) da academia francesa de ciências que viveu neste século. Só faltou saber se era endocrinologista.

\section{Saudações,}

\section{Claudio Kater, Editor-chefe, ABE\&M}

PS: Durante os almoços e nos intervalos para café do referido simpósio muitos de nós comentávamos esșa curiosidade que são os franceses, habitualmente magros e elegantes (especialmente se comparados com os mais corpulentos americanos), mas que usufruem diariamente de alimentos não somente deliciosos mas bem carregados em calorias, além de vinhos excelentes e uma variedade de queijos apetitosos ao final de cada refeição. Até onde vai a genética, onde entra o ambiente, quem faz o quê? 